\title{
Joanna Zegzuła-Nowak, Polemiki filozoficzne Henryka Elzenberga ze szkoła lwowsko-warszawska, „Biblioteka Studiów z Filozofii Polskiej”, Kraków 2017, ss. 390
}

Redagowane przez Marka Rembierza i Krzysztofa Ślezińskiego „Studia z Filozofii Polskiej", rocznik poświęcony historii filozofii polskiej, zdobyły już czytelników i skupiły wokół siebie grono badaczy rodzimej myśli, głównie tej nowszej. Już od ponad dziesięciu lat ukazują się regularnie kolejne tomy. Jedną z najnowszych inicjatyw środowiska skupionego wokół „Studiów” jest seria monografii „Biblioteka Studiów z Filozofii Polskiej”, wydawana w tym samym krakowskim wydawnictwie Scriptum, w którym ukazują się „Studia”. Przyczyny, które sprawiły, że potrzebne okazało się wydawanie tej serii, zostały wyłuszczone przez Stefana Konstańczaka, redaktora tomu. Znalazło się wśród nich przekonanie, że znajomość dziejów filozofii polskiej jest niezbędna do rozwiązania wielu problemów polskiej współczesności. Prócz tego szerokiego przesłania dla redaktorów serii ważne było i to, aby dowartościować te postaci i nurty, które - pozornie - wydają się nie mieć tylu zwolenników co zjawiska w historii filozofii polskiej uznane za dominujące czy w jakiś sposób „zwycięskie”. Konstańczak słusznie zaznacza, że krytyka wobec nurtów szczycących się większą liczbą uczniów i zwolenników nie może zostać unieważniona, gdyż - krótko mówiąc - to nie liczba zgodnych głosów decyduje o znaczeniu argumentu, ale rzeczowa ocena jego słuszności. Dodajmy, że w wielu wypadkach powszechna zgoda znajduje swoje uzasadnienie w sile argumentacji, ale o wiele bardziej intrygujące są te przypadki, w których przekonujące wywody nie znalazły zwolenników, jednakże do dziś nie mogą zostać zignorowane.

Jeśli wziąć te rozważania za dobrą monetę, to trudno byłoby znaleźć stosowniejszy temat na inaugurację serii niż polemiczne związki Henryka El- 
zenberga ze szkołą lwowsko-warszawską. Była to bowiem krytyka jednej ze szkół filozoficznych dominujących w Polsce od okresu dwudziestolecia międzywojennego, krytyka dokonana przez uczonego będącego outsiderem przez całą swoją filozoficzną karierę, filozofa, który z osamotnienia i dystansu uczynił swoje filozoficzne credo. Tym właśnie sporom poświęcona jest prezentowana tutaj książka autorstwa Joanny Zegzuły-Nowak, historyczki filozofii polskiej związanej od początku swej kariery naukowej z ośrodkiem zielonogórskim. Tytuł książki brzmi Polemiki filozoficzne Henryka Elzenberga ze szkoła lwowsko-warszawska i dokładnie oddaje jej zawartość. Autorka, podobnie jak redaktor serii, akcentuje polemiczną naturę filozofii, której problemy i stanowiska rodziły się w sporach, ma również nadzieję, że jej rozprawa podniesie poziom polemik filozoficznych w Polsce. Czy to się uda będzie można ocenić dopiero po latach. Łatwiej natomiast poddać analizie cele historycznofilozoficzne książki. Przedstawiając polemiki Elzenberga ze szkołą lwowsko-warszawską, Zegzuła-Nowak nie zamierzała rozstrzygać sporów między polemistami i wykazywać rację jednej ze stron, wydaje się jednak, że sympatia autorki znajduje się raczej po stronie samotnego filozofa niż zbiorowości szkoły lwowsko-warszawskiej. Autorka zaplanowała bowiem dołączenie postaci Elzenberga do zróżnicowanego grona filozofów nastawionych z różnych względów krytycznie do uczniów Twardowskiego, a także wykazanie wpływu, jaki te polemiki miały na dalszy rozwój filozofii w Polsce.

Aby ten cel zrealizować, konieczne było poruszenie problemów metafilozoficznych, metodologicznych oraz całego szeregu szczegółowych zagadnień filozoficznych, wokół których rozgrywała się polemika Elzenberga ze szkołą lwowsko-warszawską. Polemika ta miała niekiedy charakter jednostronny, ale ze względu na fakt, że przedmiotem rozprawy jest właśnie Elzenberg, nawet opublikowane pośmiertnie uwagi wzbogacają jego wizerunek, mimo że krytykowani przezeń przedstawiciele szkoły lwowsko-warszawskiej nie mogli na te krytyczne uwagi odpowiedzieć, ani nawet się o nich dowiedzieć.

Książka składa się z trzech nierównych objętościowo i merytorycznie rozdziałów, logicznie uporządkowanych. Pierwszy przedstawia obydwie strony sporów, a więc postać i dzieło Elzenberga z jednej strony, a szkołę lwowsko-warszawską, jej powstanie i rozwój, głównych przedstawicieli i ich filozoficzne cele - z drugiej. Obie te części rozdziału I prezentują osobne narracje, biografię Elzenberga i rozwój szkoły, przygotowują tym samym do części trzeciej rozdziału, w której wreszcie przecinają się drogi Elzenberga i szkoły lwowsko-warszawskiej. W tym przedstawieniu szkoły lwowsko-warszawskiej, które miało służyć jako tło polemik, zbyt wiele miejsca zajmuje prezen- 
tacja działalności samego Kazimierza Twardowskiego, a zwłaszcza szeroko przytaczane cytaty z wypowiedzi uczniów lwowskiego filozofa, którzy w pochwalnym tonie podnosili jego przymioty i zasługi. Byłoby może lepszym zabiegiem poszerzenie zakresu informacji o najważniejszych przedstawicielach szkoły, zwłaszcza o tych, którym szczególną uwagę poświęcił Elzenberg, tym bardziej, że z samym Twardowskim nie polemizował. W ostatniej, trzeciej, części tego rozdziału wskazano - jeszcze nie polemiczne, ale filozoficznie istotne - różnice między Elzenbergiem a przedstawicielami szkoły, wśród których przywoływany jest głównie Twardowski, a w mniejszej mierze Tadeusz Kotarbiński czy Jan Łukasiewicz. W rozdziale tym omawiany jest także epizod biograficzny, a mianowicie poparcie Tadeusza Czeżowskiego dla objęcia przez Elzenberga profesury na Uniwersytecie Stefana Batorego, mimo oporów niektórych przedstawicieli środowiska wileńskiego. Epizod ten stał się początkiem długoletniej przyjaźni obu filozofów. Zegzuła-Nowak przedstawia także osobiste relacje Elzenberga i Mieczysława Wallisa. Wśród omawianych w tym rozdziale różnic, w większości - o ile nie w całości - niemożliwych do przezwyciężenia, znajdowały się zagadnienia metafilozoficzne, jak np. problem światopoglądowej funkcji filozofii, a także stosowalności do filozofii metod logiki, możliwości i sensowności unaukowienia etyki, wartości analiz językowych, wartości intuicji jako metody poznawczej itd. Temu bardzo treściwemu i stosunkowo długiemu oraz niezwykle różnorodnemu tematycznie podrozdziałowi (60 stron) przydałby się podział na wewnętrzne części, który ułatwiłby czytelnikowi prześledzenie i wybranie obszarów, w których występowały podobieństwa, różnice i ich źródła - jak wskazuje tytuł tego podrozdziału. Tym bardziej, że obok zagadnień ściśle filozoficznych przedstawione są $\mathrm{w}$ nim również nieco mniej filozoficznie istotne kwestie o charakterze przede wszystkim biograficznym.

Esencję całej książki stanowi rozdział II, noszący bardzo długi tytuł: Henryka Elzenberga krytyka pogladów etycznych, estetycznych, ontologicznych, z zakresu historii filozofi, metodologii oraz zasad sztuki translatorskiej sformułowanych przez przedstawicieli szkoły lwowsko-warszawskiej. Wśród przedstawicieli szkoły, do których wprost krytycznie odniósł się Elzenberg, znajdują się następujący filozofowie: Łukasiewicz, Kotarbiński, Maria Ossowska, Czeżowski, Stanisław Ossowski, Władysław Tatarkiewicz (choć autorka jest słusznie świadoma jego wątpliwej przynależności do szkoły i niemożliwości uznania go wprost za ucznia tej szkoły czy ucznia Twardowskiego), Kazimierz Ajdukiewicz, Zbigniew Jordan i Władysław Witwicki. Rozpiętość problemów, do których odnosił się Elzenberg - o czym można wnosić już na 
podstawie samej listy tych nazwisk - jest więc imponująca. Autorka książki musiała zatem podjąć podobnie szerokie poszukiwania i poruszyć zagadnienia $\mathrm{z}$ wielu dziedzin filozofii. Najprościej byłoby kolejność owych polemik ująć wedle klucza chronologicznego, Zegzuła-Nowak wybrała jednak inne rozwiązanie, które okazało się trafne i świadczące o znakomitym rozeznaniu $\mathrm{w}$ omawianych problemach. Postanowiła mianowicie zaprezentować je według ich wagi i znaczenia dla filozofii w ogóle, a także dla samego Elzenberga. Rozpoczynają się więc one od fundamentalnych zagadnień metafilozoficznych i metodologicznych, a kończą na technicznych w gruncie rzeczy problemach natury filologicznej.

Nie mógł nie pozostać bez reakcji Elzenberga słynny referat Łukasiewicza pt. O metodę w filozofii wygłoszony na Zjeździe Filozoficznym w 1927 roku. Całej dotychczasowej filozofii referent przyznał jedynie wartość etyczną, estetyczną, uznał ją za zjawisko ważne w dziejach, ale akcentując błędność koncepcji filozoficznych, odmówił im wartości naukowej. Elzenberg natomiast wyżej cenił twórczy charakter filozofii i akceptując możliwość popełniania błędów, wskazywał, że i z błędu może wynikać postęp. Podobne stanowisko w okresie powojennym zajmował Czeżowski, ale dopiero dwie dekady po wystąpieniu Łukasiewicza. Interesująca byłaby odpowiedź na pytanie, czy i na ile zdanie Czeżowskiego w tym względzie wynikało z bliskiej znajomości i dyskusji z Elzenbergiem, na ile można by więc mówić o wpływie Elzenberga na jednego z przedstawicieli szkoły.

Kolejny filozof, wobec którego Elzenberg wycelował swe polemiczne ostrze, to Kotarbiński. Z krytyką Elzenberga spotkała się koncepcja praktycznego realizmu Kotarbińskiego. Wynikała ona, być może, z redukcjonistycznego pojmowania tej koncepcji przez autora Kłopotu $z$ istnieniem i autorka, mimo swej sympatii do Elzenberga, zaznacza, że nie dostrzegł on możliwości budowania kultury na wartościach pozytywnych, która - być może implicite - kryje się jednak w koncepcji Kotarbińskiego. Postulat etyki niezależnej również nie uszedł uwadze Elzenberga, który - jak i inni krytycy tej koncepcji - podkreślał niemożliwości stworzenia etyki całkowicie niezależnej od wszelkiego światopoglądu, choć i Elzenberg sam, podobnie jak Kotarbiński, starał się uniezależnić dociekania etyczne od religii. Podobna zbieżność między oboma filozofami nie mogła jednak istnieć w przypadku krytyki materialistycznych koncepcji Kotarbińskiego, w których Elzenberg nie mógł dostrzec sprawy niezwykle dlań ważnej - nie było tam bowiem miejsca na duchowość.

Ossowska i jej koncepcja uprawiania etyki również nie znalazła uznania w oczach Elzenberga, którego celem było tworzenie etyki, mającej stać się 
pewną dyrektywą działania, nie mógł więc zgodzić się na zredukowanie postępowania badawczego etyka do opisywania i klasyfikowania. Można zatem w pewnym uproszczeniu przedstawić ten spór jako metaetyczny rozdźwięk między etyką normatywną i etyką opisową, porządkującą. Bardziej szczegółowym etycznym problemem podniesionym przez Elzenberga była też refleksja krytyczna nad Ossowskiej rozważaniami o możliwości odróżnienia wypowiedzi opisowych od oceniających oraz dyskusja, co prawda tylko epistolarna, nad jej koncepcją wzoru obywatela i wzoru moralnego w ogóle.

Inny charakter miała dyskusja Elzenberga z Czeżowskim, z długoletnim uniwersyteckim współpracownikiem z Wilna i Torunia, po prostu z bliskim kolegą, na marginesie pracy którego Elzenberg dał wyraz własnym filozoficznym dążeniom. Podstawowym tematem tej dyskusji było zagadnienie sensu życia i różne jego rozumienia.

Estetyka stanowiła natomiast obszar polemik z Ossowskim. Recenzując jego książkę pt. U podstaw estetyki, Elzenberg wydobył z niej krytycznie wszystkie te tendencje autora, które wydały mu się pozytywistyczne, empiryczne, opisowe. Wydawało mu się to odzierać estetykę z tego, co w niej najistotniejsze, co zdawało się zbyt ulotne do zbadania przez filozofa należącego do kręgu szkoły lwowsko-warszawskiej. Estetyka była dla Elzenberga dziedziną aksjologii, mającą za przedmiot obiektywne wartości, a nie fenomen sztuki czy przeżycia estetyczne. Dalsze tematy polemiki Elzenberga dotyczyły pojęcia ekspresji estetycznej oraz natury sądu estetycznego.

Historia filozofii stała się przedmiotem polemiki Elzenberga $\mathrm{z}$ Tatarkiewiczem, zawartej w tekście recenzji, której poddana została, wówczas jeszcze tylko dwutomowa, Historia filozofii, wydana w 1931 roku. Nie znalazło uznania w oczach Elzenberga ograniczenie perspektywy dzieła do obszaru cywilizacji europejskiej, poruszył także problem obiektywizmu i bezstronności, które - dla odmiany - zyskały jego pochwałę. Po trzech dekadach Elzenberg zajął się kolejną historyczną syntezą Tatarkiewicza, a mianowicie Historią estetyki. I w niej znalazł wiele wartościowego materiału, ale i ona nie była bez wad, gdyż jej autor ograniczał rozumienie piękna do sfery zmysłowej, a ponadto rozdzielał niepotrzebnie wartości etyczne i estetyczne. Co ważne, między oboma filozofami wywiązała się rzeczowa i uprzejma korespondencja.

Podobnie historię filozofii, a konkretnie interpretację stanowiska George’a Berkeley’a, ma za przedmiot polemika Elzenberga z Ajdukiewiczem. Dotyczyła ona bowiem tego, jaki pogląd należy mu przypisać, czy idealizm immanentny, czy tylko subiektywizm ontologiczny, wedle którego istnienie przedmiotu jest uwarunkowane jego istnieniem w świadomości jakiegoś 
podmiotu. Wedle Elzenberga nie oznacza to jednak, że należy przedmiotowi odmówić jakiegokolwiek istnienia poza umysłem świadomego podmiotu, jak interpretował to stanowisko Ajdukiewicz. Czynił to jednak błędnie, argumentował Elzenberg, zwłaszcza jeśli w egzegezie Berkeley’a oprzeć się na jego pismach późnych. Ajdukiewicz odpowiedział na te zarzuty listownie, podnosząc spójność i jasność interpretacji immanentnej i skromniejszy zestaw pism Berkeley’a, na których oparł swoje poglądy.

Zgodnie z deklaracją autorki o malejącej ważności kolejnych polemik jako następna pojawiła się w książce wzmianka nt. notatki Elzenberga dotyczącej niewłaściwego sposobu referowania poglądów innych myślicieli. Idzie tu mianowicie o doktorat Jordana o filozofii Platona, w którym pozwolił on sobie na użycie słowa „rzekomo” w zdaniu referującym myśl innego badacza. Ten zabieg przyciągnął uwagę Elzenberga, który uznał takie postępowanie za nieuczciwe i krzywdzące, za pozbawioną obiektywizmu manipulację pod pozorem bezstronnego referowania. Ostatni zaś wątek polemiczny dotyczy prac redakcyjnych Elzenberga nad tekstem Platońskiego Eutydema w przekładzie Witwickiego, który ukazał się dopiero pośmiertnie w 1957 roku w Bibliotece Klasyków Filozofii. Redaktor dokonał korekty i poprawek tekstu Witwickiego, tłumacza, który w przeciwieństwie do redaktora, miał olbrzymie doświadczenie translatorskie i przez pół wieku zajmował się spolszczaniem dialogów. Elzenberg eliminował więc pomyłki tłumacza, niepotrzebne modernizacje tekstu, sądził bowiem, że dokonywał na tekście ostatniego szlifu, którego już nie zdążył zrobić tłumacz. W tych dwóch mniejszej wagi kwestiach, jakkolwiek trafnie autorka je zanalizowała, tytuł rozdziału jej książki traci adekwatność. Witwicki bowiem w istocie nie sformułował zasad tłumaczenia tekstów klasycznych, które następnie zostały przedyskutowane przez Elzenberga, ale ten ostatni dokonał jedynie poprawek tekstu, którego kształt wynikał z długoletniej i odnoszącej niewątpliwe sukcesy praktyki translatorskiej Witwickiego. Podobnie Jordan, nie podał metody referowania cudzych myśli, jedynie raz zreferował je w sposób pozbawiony obiektywizmu i uczciwości. Krótko mówiąc, Elzenberg nie tyle dyskutował zasady sformułowane przez Jordana i Witwickiego, ile skrytykował ich błędne - jego zdaniem praktyki referowania i tłumaczenia, co w przypadku Jordana sprowadza się zasadniczo do jednego słowa. Ponadto polemika z Jordanem i Witwickim dotyczy kwestii znajdujących się poza zasadniczym obszarem zagadnień filozoficznych szkoły lwowsko-warszawskiej.

Wszystkie spory Elzenberga $\mathrm{z}$ przedstawicielami szkoły lwowsko-warszawskiej nie tylko zostały przez autorkę wyczerpująco omówione, ale także 
dokonała ona próby przebadania ich przyczyn i głębszych uwarunkowań. Rozdział drugi stanowi zasadniczą oś całej książki. Rozdział trzeci jest zaś właściwie autorskim dopowiedzeniem, mającym prezentować wpływ zarysowanych wcześniej polemik Elzenberga na dalszy rozwój filozofii w Polsce (Wplyw polemik filozoficznych Henryka Elzenberga ze szkoła lwowsko-warszawską na współczesna filozofię polską).

Jest pewną przesadą domniemywanie przez autorkę wpływu omawianych polemik na dyskusje filozoficzne wykraczające poza środowisko polskie (s. 289), na co nie znajdziemy w książce przykładów. Rozdział III zawiera jednak wartościowy zarys recepcji myśli Elzenberga i skrótową historię badań nad jego spuścizną, podkreślając zasługi filozofów i historyków filozofii z różnych ośrodków intelektualnych kraju. Autorka chciała podobnie potraktować spuściznę szkoły lwowsko-warszawskiej, tj. ukazać jej dalszą recepcję, ale szczupłość miejsca przeznaczona na ten cel nie pozwoliła na wyczerpanie tematu. Podjęte w tym podrozdziale zostały, prócz pochwał dla działalności szkoły, zagadnienia różnej doniosłości, od istotnie filozoficznych, jak np. zagadnienie ateizmu Kotarbińskiego, po marginalne, jak np. spory interpretacyjne wokół jubileuszowego przemówienia Ajdukiewicza. Tytuł ostatniej części rozdz. III daje bliższe rozeznanie w intencjach autorki, gdyż wpływ owych polemik Elzenbergowsko-lwowsko-warszawskich został określony jako „analogie, nawiązania, pokłosia”. Ta niezobowiązująca forma dała autorce możliwość selekcji omawianych zagadnień wedle własnego klucza, wybierając te, które były i są jej bliższe (także środowiskowo) i umożliwiając również sprawozdanie z tych, w których trudniej dopatrzeć się bezpośredniego wpływu polemik Elzenberga ze szkołą, a dostrzec można pewne „analogie” przedmiotowe.

Książkę zamyka trzystronicowe zakończenie, w którym powtórzone zostały cele rozprawy i struktura książki. Całość uzupełniają obszerna bibliografia i indeks nazwisk.

Podsumowując, najważniejszą i najbardziej wartościową część książki stanowi rozdział drugi. W nim czytelnik znajdzie odpowiedź na pytanie o przedmioty, cele, uwarunkowania i motywy polemik Elzenberga z przedstawicielami szkoły lwowsko-warszawskiej. Do tego esencjalnego rozdziału historycznie wprowadza rozdział pierwszy, a trzeci stanowi wyraz autorskiego wyboru i oceny dalszego wpływu problematyki przedstawionej w rozdziałach wcześniejszych na filozofię współczesną w Polsce.

Wracając do głównego tematu książki: jakie jest oblicze Elzenberga jako polemisty? Uderza klasa prowadzonych polemik, nigdy nie było jego celem "dobicie” adwersarza. Przykłady na to znajdują się na wielu kartach książki, 
jest to też skonstatowane wprost. Nie bez znaczenia dla oceny celu polemik jest także zaniechanie przez filozofa sporów ze szkołą lwowsko-warszawską w czasie, gdy ta była przedmiotem ataków ze strony marksistów.

Autorka wykorzystała bogatą literaturę przedmiotową dotyczącą Elzenberga, którą zdążyła przez lata swoich badań nad jego spuścizną poznać i przeanalizować. Należy dodać, że kilkuletnie prace autorki nad myślą Elzenberga doprowadziły ją do wielu odkryć archiwalnych, które znacząco wzbogaciły bazę źródłową nie tylko omawianej tu pozycji, ale i filozofii polskiej w ogóle. Książka powinna znaleźć wdzięcznych odbiorców nie tylko wśród znawców i miłośników twórczości autora Kłopotu $z$ istnieniem, lecz także badacze szkoły lwowsko-warszawskiej i jej recepcji natrafią w niej na interesujące treści.

$\mathrm{Na}$ koniec jeszcze kilka słów o formie wydawniczej książki. Jest ona bez zarzutu, pozycja została bowiem wydana starannie, a jej historycznofilozoficzny charakter i warsztat pracy autorki został podkreślony przez graficzny projekt okładki, na której znajdują się fragmenty rękopisów głównego bohatera pracy. Jeśli idzie o styl i język, to potoczysta narracja autorki wydaje się nawet uwypuklać dynamiczny charakter referowanych zagadnień.

Wracając do merytorycznej oceny całej książki, trzeba stwierdzić, że Zegzule-Nowak udało się zrealizować cel rozprawy, a mianowicie przekonująco przedstawić czytelnikom nieoczywiste pole aktywności introwertycznego filozofa. Jego polemicznego, a niekiedy nawet zaczepnego oblicza nie będzie można już spychać na plan dalszy. Polscy marksiści nie kryli swych krytycznych celów i metod, podobnie, choć w lepszym stylu, niezrównanym polemistą był np. Leon Chwistek. Powszechnie wiadomo, że nie unikali oni sporów, co do Elzenberga - przekonanie to uzasadnia dopiero książka Zegzuły-Nowak.

Tomasz Mróz

Uniwersytet Zielonogórski, Polska e-mail: tmroz1@gmail.com 